\title{
Sovereignty, Democracy and Neutrality: French Foreign Policy and the National-Patriotic Humanitarianism of the French Red Cross, 1919-1928
}

\author{
Romain Fathi (D) \\ Flinders University/Centre d'Histoire de Sciences Po, SSS Building, Flinders University, GPO Box 2100, Adelaide 5000 SA, \\ Australia \\ Email: romain.fathi@flinders.edu.au
}

(Received 24 November 2020; revised 17 August 2021; accepted 7 September 2021)

Recent historiography pertaining to the International Red Cross has generally emphasised the transnational scale as best suited for analysing this global movement. Using the French Red Cross as a case study, this article suggests that focusing on the national scale, or even on the national-imperial scale, does not exclude transnational approaches but enriches them. In doing so, it highlights the dialectic between scales of humanitarian activity and complicates our understanding of the Red Cross movement in the early twentieth century. The article examines how the French Red Cross strived for its independence within the broader Red Cross world in a postwar humanitarian context increasingly dominated by transnational organisations. It also argues that in the 1920s the French Red Cross, a traditional auxiliary of the French army, became an arm of the French Foreign Office, advancing French diplomacy and sovereignty.

The decade that followed the First World War witnessed an unprecedented expansion of the works of humanitarian and international organisations. ${ }^{1}$ Rich scholarship documents the role of these organisations, including, but not limited to, Save the Children, the International Labour Organization, the League of Nations, the European Relief and Rehabilitation Administration, and the International Committee of the Red Cross. The perspective of how national societies interacted with international organisations has, however, been less prevalent in the literature, given the legitimate focus on internationalism and transnationalism. This article considers how the Central Committee of the French Red Cross navigated a postwar environment increasingly dominated by transnational humanitarian organisations. It looks at how the French Red Cross strived for its independence while learning how to engage with international and humanitarian organisations and, in particular, the newly-born League of Red Cross Societies (LRCS). Crucially, it explores a contrast between the national-patriotic character of the French Red Cross and the transnational humanitarian agenda of the broader Red Cross movement, especially as that contrast arose around the question of the democratic character and representative protocols of humanitarian organisations.

In doing so, this article argues that in the 1920s, under the presidency of General Paul Pau, the French Red Cross, a traditional auxiliary of the French army, became an arm of the French Foreign Office, a semi-official and semi non-official channel through which to advance French diplomacy. The national-patriotic make-up of the French Red Cross was not a new post-First World War

\footnotetext{
1 See Bruno Cabanes, The Great War and the Origins of Humanitarianism, 1918-1924 (Cambridge: Cambridge University Press, 2014) and Daniel Gorman, International Cooperation in the Early Twentieth Century (London: Bloomsbury, 2019). 
phenomenon and had already been observed during the Franco-Prussian war. Furthermore, the growing authority of the state in its affairs had increased since the Paris Commune of $1871 .^{2}$ The aftermath of the First World War was, therefore, a culminating process for the French Red Cross's patriotism and proximity to the state and its foreign policy, rather than a starting point. This is documented through an analysis of the French Red Cross's ambivalent relationship with the LRCS that nourished what Irène Herrmann has referred to as a concurrence humanitaire between the International Committee of the Red Cross (ICRC) and the nascent LRCS in order to advance French interests. ${ }^{3}$ Analysing this ambivalence reveals that the French Red Cross's trajectory in the uncertain waters of the postwar humanitarian world was one of autonomy vis-à-vis the LRCS, the ICRC and transnational humanitarianism more broadly. This trajectory was a learning process for the French Red Cross. Through shifting partnering and collaborating with the LRCS and the ICRC, the French Red Cross tried to discover which body was better constituted to support French national interests in the postwar world. This points to a key issue for transnational humanitarian organisations and how they could attempt to practise forms of democratic representation while aggregating and mediating between sovereign interests of national organisations. To begin with, the article paints the postwar landscape within which the French Red Cross operated and considers its contribution to the creation of the LRCS. It then establishes how animosity toward Germany guided its stands on various matters that pertained to the organisation of the Red Cross movement at an international level. The article then investigates why the LRCS relocated its headquarters from Geneva to Paris and how the French Red Cross sought to align its international activities to French foreign policies. Finally, this article examines the French Red Cross's position on the proposed fusion of the LRCS and the ICRC through the 1920s.

While this article uses the terminology 'French Red Cross', it must be acknowledged that this space was a heterogeneous grouping of associations. Although the term Croix-Rouge française was used to speak about the Red Cross movement in France before the First World War, the French Red Cross as an institution was not formalised until 7 August $1940 .{ }^{4}$ Prior to that date, three associations - la Société de secours aux blessés militaires (SSBM), l'Union des femmes des France, and l'Association des dames françaises - made up the French Red Cross movement and were represented in a body called the Comité central de la Croix-Rouge française. The SSBM, as an auxiliary to the French army, held moral ascendency over the other two associations, with high-profile members within its ranks (army generals, aristocrats, diplomats). While women had a central role in both l'Union des femmes des France and l'Association des dames françaises, the central committee of the SSBM was male-dominated; it formed the core component of the Comité central de la Croix-Rouge française, presided over by General Paul Pau, also the president of the SSBM from 26 February 1918. ${ }^{5}$ The Central Committee - referred to as the French Red Cross (FRC) in this article - was the body in charge of representing and leading the many branches and associations that were part of the French Red Cross movement. In this role, the FRC also dealt with matters relevant to the international organisation of the Red Cross movement. As a caveat, and based on files consulted in French departmental archives documenting the activities of local branches of the FRC's three associations, it must be noted that such branches were mostly concerned with local programmes of work (tuberculosis, milk for the newborn, the poor, reconstruction works, etc.) and often did not think of their mandate as one of global humanitarianism. ${ }^{6}$ As the saying goes: charité bien ordonnée commence par soi-même

\footnotetext{
2 Bertrand Taithe, "The Red Cross Flag in the Franco-Prussian War: Civilians, Humanitarianism and War in the "Modern" Age', in Roger Cooter, Mark Harrison, and Steve Sturdy, eds., Medicine, War and Modernity (Stroud: Sutton Publishing Ltd, 1998), 22-47.

3 Irène Herrmann, 'Décrypter la concurrence humanitaire: le conflit entre Croix-Rouge(s) après 1918', Relations internationales, 151 (2012), 91-102. On the humanitarian competition, see also: Cédric Cotter, (S')Aider pour Survivre. Action humanitaire et neutralité suisse pendant la Première Guerre mondiale (Geneva: Georg, 2017), 465-99.

4 Frédéric Pineau, La Croix-Rouge Française 150 ans d'histoire (Paris: Autrement, 2014), 102-3.

5 Bulletin international des sociétés de la Croix-Rouge, Geneva, 195 (1918), 394.

6 See for example the rich collection of interwar French Red Cross archives at the Archives Départementales de la Marne (both the Reims and Châlons-en-Champagne sites) and, to a lesser extent, those of the Pas-de-Calais and Somme departments.
} 
(charity begins at home), and there was much to do in post-First World War France. In turn, this local and national focus meant that while the Central Committee was the voice of the French Red Cross on international Red Cross matters, its clout over such matters and its ability to see them being transposed at local level was limited. In addition, the Central Committee - itself mostly an emanation of the SSBM also primarily conceived its role as a national auxiliary to the French army and to the French state.

As much of the archives of the French Red Cross were lost during the 1940 German invasion of France, this article mostly relies on archives kept at the French Foreign Affairs ministry (Ministère des affaires étrangères or MAE). ${ }^{7}$ Those rich and, to this point, unexplored and untranslated archives document the work of the Central Committee of the FRC and its engagement with the wider Red Cross world, an engagement closely monitored by the Quai d'Orsay (the French Foreign Office). The selection of this specific source base is, in itself, a methodological and historiographical contribution. By recentring on the nation-state in the Red Cross world, the article raises questions about the reading of humanitarianism, in some of the current historiography, as a non-state phenomenon, accessed via the records of non-governmental organisations and framed globally and transnationally. ${ }^{8}$ In the present case study, it becomes clear that the involvement of the state in its national-imperial dimension was central in shaping how the French Red Cross engaged with international humanitarianism. This article also contributes to the nascent historiography on the French Red Cross that has so far mostly focused on two broad periods: foundation to 1918, and 1940 to the present, with an underscrutinised postwar period. ${ }^{9}$ Rather than considering the Central Committee's operations from a Genevan or American perspective, or from the perspective of international organisations (LRCS, ICRC, LON), this article seeks to present a French outlook on how the French Red Cross thought of itself on the international stage, but also thought of the international stage, and navigated the postwar period. This French outlook is understood both as a perspective - that of the French Red Cross and French institutions - and as a methodology, using archival material written in French in a historiography that heavily relies on English-language primary and secondary materials.

\section{A World Order Reconfigured}

In 1919, France was triumphant but battered. It had a large army, an even larger debt, had lost a significant proportion of its population, and many of its départements were devastated. ${ }^{10}$ Given the rising importance of the United States and both its actual and perceived role in French imagination about helping to win the war, the United States became an important player in French diplomatic endeavours, including those pertaining to the international Red Cross movement. Whether they liked it or not, internationalism prevailed among French leaders, as France alone would not be able to coerce Germany and its former enemies to abide by the peace treaties. ${ }^{11}$ France, which remained profoundly anti-German, accepted the idea of a League of Nations put forward by President Wilson. The proposed Covenant of the League of Nations included an article that related to the Red Cross movement. ${ }^{12}$

\footnotetext{
7 Conversation with Virginie Alauzet, Archivist of the French Red Cross, 13 Dec. 2018.

8 Stephen Sawyer, 'Ces nations façonnées par les empires et la globalisation. Réécrire le récit national du XIXe siècle aujourd'hui', Annales. Histoire, Sciences Sociales, 69, 1 (2014), 117-37.

9 See for example: Bernard Chevallier, La Croix-Rouge Française (Paris: Le Centurion, 1986); Frédéric Pineau, La Croix-Rouge Française 150 ans d'histoire; Rachel Chrastil, 'The French Red Cross, War Readiness, and Civil Society, 1866-1914', French Historical Studies, 31, 3 (2008), 445-76; Jennifer Johnson, 'The Limits of Humanitarianism: Decolonization, the French Red Cross, and the Algerian War', in A. Moses, M. Duranti, and R. Burke, eds., Decolonization, Self-Determination, and the Rise of Global Human Rights Politics (Cambridge: Cambridge University Press, 2020), 79-108.

10 An excellent summary of the scale of devastation is provided in Serge Berstein and Pierre Milza, Histoire de la France au XXe siècle. I. 1900-1930 (Paris: Perrin, 2009), 288-93.

11 Ibid., 294-336; see also Marie-Renée Mouton, 'La France et la Société des Nations en 1922', Guerres mondiales et conflits contemporains, 193 (1999), 101-15.

12 The idea of a League of Nations had, in France, a history that well pre-dated the First World War. See Jean-Michel Guieu, Le rameau et le glaive. Les militants français pour la Société des Nations (Paris: Les Presses de Sciences Po, 2008), 18-26.
} 
Article 25 stipulated that: 'The Members of the League [of Nations] agree to encourage and promote the establishment and co-operation of duly authorised voluntary national Red Cross organisations having as purposes the improvement of health, the prevention of disease and the mitigation of suffering throughout the world. ${ }^{13}$ This article emanated from President Wilson's support of an idea of Henry Pomeroy Davison (Chairman of the War Council of the American Red Cross) that an international institution within the Red Cross movement should be created to oversee peace time activities: a non-governmental, independent, and democratic humanitarian counterpart to the League of Nations that would eventually become the LRCS. ${ }^{14}$ In the minds of LRCS proponents, and in the wake of the 'war to end all wars', it was time for the Red Cross movement to go beyond wartime work, and it seemed to them that the ICRC was not best placed to achieve their new programme. ${ }^{15}$ Indeed, they wished to create a new federated and democratic body that would promote and coordinate peacetime humanitarian work, such as the promotion of good health, fighting disease, and relieving those affected by catastrophes, both manmade and natural. ${ }^{16}$ In France, Davison's vision for the Red Cross's peacetime work was already discussed and understood by the FRC, albeit at a smaller and national scale. ${ }^{17}$ During the First World War, the French Red Cross had considerably enlarged the scope of its action, helping civilians, refugees, and those affected by the war alongside its more traditional role of auxiliary to the army. ${ }^{18}$ When the guns fell silent in November 1918, tuberculosis and infant mortality became major causes for the FRC. The transition to peace and peacetime work was in everyone's mind, and in fact that moment was anticipated and prepared during the later years of the war itself. Now that the conflict had officially ceased with an armistice, the great work of reconstruction could begin.

French support for the creation of the LRCS emerged, in the first instance, from the French government. ${ }^{19}$ The Central Committee very much saw itself as an auxiliary of the French state and acted

On France's support for a stronger League of Nations than the one devised by American and British representatives see: Margaret MacMillan, Paris 1919. Six Months that Changed the World (London: John Murray, 2019), 95, 103; Serge Bernstein, ed., Ils ont fait la paix. Le traité de Versailles vu de France et d'ailleurs (Paris: Les Arènes, 2018), 119, 124-5.

13 Covenant available at: https://avalon.law.yale.edu/20th_century/leagcov.asp (last visited 15 Jun. 2021).

14 On Davison's vision for and role in the creation of the LRCS, see Melanie Oppenheimer and Carolyn Collins, Henry Pomeroy Davison (Geneva: Société Henry Dunant, 2019), 47-71.

15 Since its creation, the ICRC had been dealing quasi-exclusively with war-related matters, be that through the shaping of IHL, its wartime work during several conflicts, or its work with POWs. Peacetime work was neither within its scope nor an established agenda that the Geneva-based committee was interested in until 1919.

16 Daphne Reid and Patrick Gilbo, Beyond Conflict: The International Federation of Red Cross and Red Crescent Societies 1919-1994 (Geneva: International Federation of Red Cross and Red Crescent Societies, 1997), 34-41.

17 Other national societies as well, such as those of the United States and Japan, were already doing natural disaster work before the war.

18 On this historical role, see Rachel Chrastil, 'The French Red Cross, War Readiness, and Civil Society, 1866-1914', French Historical Studies, 31, 3 (2008), 445-76. The present article has a focus on the Comité central of the FRC. The FRC was a broad church comprising different currents and associations. The work of these associations with French civil society is documented by Chrastil.

19 In comparison to the International Committee of the Red Cross (ICRC) formed in 1863, the LRCS has attracted scant scholarly attention (see Oppenheimer et al.). When it has, the role of the American Red Cross in its development has been central to historians' investigations, as the LRCS was in its early days mostly an American-driven and funded initiative. Melanie Oppenheimer, Susanne Schech, Romain Fathi, Neville Wylie, and Rosemary Cresswell, 'Resilient Humanitarianism? Using Assemblage to Reevaluate the History of The League of Red Cross Societies', The International History Review, 43, 3 (2021), 579-97. The LRCS is now known as the International Federation of Red Cross and Red Crescent Societies (IFRC) and is based in Geneva. Previous studies on the LRCS include John F. Hutchison, "Custodians of the Sacred Fire": The ICRC and the Postwar Reorganisation of the International Red Cross', in Paul Weindling, ed., International Health Organisations and Movements 1918-1939 (Cambridge: Cambridge University Press), 26-32; Bridget Towers, 'Red Cross Organisational Politics, 1918-1922: Relations of Dominance and the Influence of the United States', in Paul Weindling, ed., International Health Organisations and Movements 19181939, 36-55. Caroline Moorehead, Dunant's Dream: War, Switzerland and the History of the Red Cross (New York: Carroll \& Graff, 1999), 260-84; Julia Irwin, Making the World Safe: The American Red Cross and a Nation's Humanitarian Awakening (Oxford: Oxford University Press, 2013), 143-51. Recent scholarship is also decentralising 
in concert with it, thereby also contributing to the LRCS's formation. French war leader Georges Clemenceau, Président du Conseil from 1917 to 1920, 'approved in the most complete manner that can be' the ideas formulated by Henry P. Davison in view of the creation of the LRCS, ideas he knew were supported by President Wilson. ${ }^{20}$ At this very moment Clemenceau was negotiating the future Treaty of Versailles and was keen to support American-driven initiatives so that in turn he could receive American support for French visions for the new world order. ${ }^{21}$ As noted by Peter Jackson, this was also a time when Clemenceau insisted on the need for a new approach to peace and international security', an agenda that global humanitarianism and public health could strengthen. ${ }^{22}$ Clemenceau made his support for Davison's ideas known at a large dinner organised in Paris by Davison on 21 February 1919. ${ }^{23}$ A few weeks later, the newly formed Committee of Red Cross Societies that included representatives of the national Red Cross societies of the United States, Britain, Japan, Italy and France held a large medical conference in Cannes, from 1 to 11 April $1919 .{ }^{24}$ Eminent medical specialists were invited to propose a peacetime plan to fight disease and improve hygiene across the world. ${ }^{25}$ The peacetime plan also served to justify the foundation of the LRCS, given that such an ambitious programme of work would not be completed overnight. With the Cannes conference, the organising committee had laid the scientific justifications for the creation of the LRCS, which it formalised officially a few weeks later on 5 May 1919 at the Regina Hotel in Paris. ${ }^{26}$ Consumed as they were by the proceedings of the Paris Peace Conference, very few French newspapers reported on the creation of the league. ${ }^{27}$ The American origins of the league were, however, noted in the few articles that reported on its creation, and so was the fact that it was to be a humanitarian counterpart to the League of Nations. ${ }^{28}$

\section{Advancing France's anti-German Campaign under the Red Cross Banner}

Both the creation of the LRCS and its French support initially worried the ICRC, the body that had headed the Red Cross movement since 1863. France was prompt to understand that having a new player within the Red Cross world - the LRCS - could be useful should the FRC wish to further assert its independence from Geneva-based ICRC initiatives, such as those detailed below. Certainly, as opposed to the ICRC, the LRCS presented a major advantage for the French in 1919: it did not profess neutrality, and the Germans were not part of it. Until the end of France's occupation of the Ruhr in 1925, French policies tried to isolate Germany, a programme also supported by the French Red Cross.

our understanding of the LRCS; see Yoshiya Makita, 'The Alchemy of Humanitarianism: The First World War, the Japanese Red Cross and the Creation of an International Public Health Order', First World War Studies, 5, 1 (2014), 117-29.

20 'Président $d u$ Conseil' during France's Third Republic can be equated to 'Prime Minister'.

21 The French were also well aware of the wealth amassed by the American Red Cross and the significant role it had played in France and Europe to support populations affected by the war. See for instance: Julia Irwin, 'Nation Building and Rebuilding: The American Red Cross in Italy During the Great War', The Journal of the Gilded Age and Progressive Era, 8, 3 (2009), 407-39; Ernest Bicknell, With the Red Cross in Europe, 1917-1922 (Washington, DC: American National Red Cross, 1938).

22 Peter Jackson, Beyond the Balance of Power: France and the Politics of National Security in the Era of the First World War (Cambridge: Cambridge University Press, 2013), 232.

23 'Croix-Rouge. Un programme d'actions des Croix-Rouge', Le Gaulois, 22 Feb. 1919.

24 Proceedings of the Medical Conference held at the initiative of the Committee of Red Cross Societies, Cannes, France, April 1 to 11, 1919 (Geneva: The League of Red Cross Societies, 1919).

25 Mobilising experts to justify a programme of works was a feature of the period. See Davide Rodogno, Bernhard Struck, and Jakob Vogel, eds., Shaping the Transnational Sphere: Experts, Networks and Issues from the 1840s to the 1930s (New York: Berghahn Books, 2015).

26 Melanie Oppenheimer, “A Golden Moment?”: The League of Red Cross Societies, the League of Nations and Contested Spaces of Internationalism and Humanitarianism, 1919-1922', in Joy Damousi and Patricia O’Brien, eds., League of Nations: Histories, Legacies and Impact (Melbourne: Melbourne University Press, 2018), 8-27.

27 'L'œuvre des Croix-Rouge', Le Populaire de Paris, 8 May 1919.

28 'Une conférence internationale entre alliés', Le Populaire de Paris, 24 Mar. 1919. 
On 12 December 1919, for example, the ICRC invited all national societies of the Red Cross to its Tenth International Conference, to be held in Geneva on 1 September 1920. The French Red Cross, supported by the French government, judged as 'inadmissible' that its delegates would meet with those of former enemies, those from Germany in particular, and refused the latter's attendance. ${ }^{29}$ Letters were also sent to France's main allies to ensure that other national societies would support the French position. Both the French Red Cross and the French government were adamant on this point: Germany was to be excluded from the new world order, even in the humanitarian space which it continued to be a part of through its engagement with the ICRC. The Belgian government immediately sided with France on this matter. ${ }^{30}$ General Pau wrote to Gustave Ador, the president of the ICRC, to enumerate the reasons as to why the FRC and the French government opposed the timing of the Tenth International Conference of the Red Cross. Pau also added that one of the agenda items for the future ICRC conference - 'the subsequent development of Red Cross national societies in their peacetime' activities $^{31}$ - pertained to matters that 'seem to come under the competencies of the League of Red Cross Societies rather than those of the ICRC'; he went on to discuss the new league and its attributions. ${ }^{32}$ Pau, a celebrated war veteran of the Franco-Prussian War and a First World War general, was also an astute diplomat who had previously been sent on several diplomatic missions by the French government, including in the Balkans, Russia, Australia and New Zealand. ${ }^{33}$ Pau's reference to the LRCS, although politely expressed, was a shot across the bow to Ador, a conscious attempt to use the existence of the LRCS to keep the ICRC in check over its Tenth International Conference, a signal that the FRC was keeping its options open as to what matters it would discuss and with whom. Pau asked that the planned conference be adjourned for a full year.

Within a few weeks, the French had mounted a successful campaign against the holding of the Tenth International Conference of the Red Cross in September 1920. With France and Belgium resolutely out, and Britain having expressed its reserve, Ador could only defer, and he postponed the conference by seven months, until 30 March 1921. When he announced the postponement, Ador reminded national societies' presidents that the motives of this conference were purely humanitarian. However, as the consequences of the war were progressively being addressed, Ador knew that he had to act quickly to stake out a claim to the perimeter and parameters for the new ICRC's peacetime work, which the LRCS sought to carve out for itself. ${ }^{34}$ The French obsession with Germany - which slowed down the agenda of the ICRC - bought some time for the LRCS to develop its programme and establish itself, but the French and Belgians also campaigned against Germany with the latter organisation. At a LRCS Board of Governors' meeting, the FRC opposed the admission of the national societies of former enemies, something possible in 1920 when a unanimous vote was necessary to accept new societies in the league, a rule that was subsequently changed. ${ }^{35}$ The French knew of the ICRC and the

29 General Pau to Alexandre Millerand (Président du Conseil), 12 Feb. 1920, in file Unions Internationales 1139, MAE; Alexandre Millerand (Minister for Foreign Affairs as well as Président du Conseil at the time) to General Pau, 21 Feb. 1920, in file Unions Internationales 1139, MAE.

30 Pierre de Margerie (French Ambassador to Belgium) to Alexandre Millerand, 9 Mar. 1920, in file Unions Internationales 1139, MAE.

31 Convocation, $190^{\mathrm{e}}$ circulaire, ICRC, 12 Dec. 1919, in file Unions Internationales 1139, MAE.

32 General Pau to Gustave Ador (ICRC President), 31 Mar. 1920, in file Unions Internationales 1139, MAE.

33 In 1920, Pau also became a member of the central committee of the 'Ligue des Patriotes, ligue de vigilance pour le maintien de la paix', a reformed French nationalist movement. La Presse, 28 May 1920, 2. (Accessible via Gallica).

34 Gustave Ador, circulaire $n^{\circ} 195$, ICRC, in file Unions Internationales 1139, MAE. See also Clyde Buckingham, For Humanity's Sake: The Story of the Early Development of the League of Red Cross Societies (Washington, DC: Public Affairs Press, 1964), 121-5.

35 Notes from M. de la Boulinière (French member of the LRCS's Board of Governors), written in March 1920 and sent to the French Minister for Foreign Affairs in July, in file Unions Internationales 1139, MAE. Originally, Article IV of the bylaws of the LRCS stipulated that admission of national Red Cross societies to the League of Red Cross Societies required a unanimous vote of the League's Board of Governors. By 1922 Resolution VI of the March General Council meeting encouraged the Board of Governors to take all necessary steps to invite as many national Red Cross societies as possible to become members of the LRCS, which resulted in amendments of the by-laws in subsequent years, paving the way for a 
LRCS's 'courteous duel', as Monsieur de la Boulinière, the French member of the LRCS's Board of Governors, reported in his board's meeting notes. De la Boulinière even felt that the impressive American Red Cross's pledged cash contribution $(\$ 500,000)$ to the LRCS's budget would 'if not completely absorb the International Committee of Geneva would at least considerably restrict its reach and importance'. He continued: 'M. Ador has been apprised of the goal pursued by M. Davison, Grand Master of the League of Red Cross Societies', inferring that the ICRC would either be absorbed by the much richer LRCS or disappear in its current form. ${ }^{36}$ As it became clear to Ador that the LRCS had the financial backing to continue its operation, Ador became increasingly frustrated by its existence. $^{37}$

As if the rescheduling of the Tenth International Conference on the initiative of the French had not been enough, once its postponement had been secured, the French government through the FRC asked the ICRC to obtain from the German Red Cross an explicit disavowal of wartime violations of the Geneva Convention made by the German army. ${ }^{38}$ The German Red Cross said it could do so if other national societies, such as that of France, did the same, which of course outraged the FRC. The FRC's relentless determination to undermine the German Red Cross - and therefore Germany - was in line with French foreign policy at the time, which demanded that Germany should pay for the war damages it had caused. This sentiment was widely shared among the French population and those publicly representing it. ${ }^{39}$ It is important to note that much of the legitimacy of the French government then derived from its tough stance on Germany, in particular with regard to war reparations and demilitarisation. These agendas also drove the involvement of the French in the League of Nations, in particular on the disarmament front. ${ }^{40}$ Both the French and Belgian Red Cross societies made their attendance at the adjourned Tenth International Conference conditional on the German Red Cross's public disavowal of German war atrocities and breaches of the Geneva Convention. Despite Ador's skilful efforts to seek conciliation, the demands of these national societies could not be met satisfactorily. France and Belgium thus officially declined the invitation to Geneva. ${ }^{41}$ Not only had they managed to postpone the Tenth International Conference of the Red Cross by seven months, they also then refused to attend the adjourned meeting. ${ }^{42}$

When discussions were held about Germany's membership of the LRCS in 1920, France, as a founding member, opposed it. In 1921, this opposition was renewed as both Belgium and France agreed to new national societies joining the LRCS but again denied the membership of Germany. In the spring of 1922, as the second meeting of the LRCS's General Assembly approached, the French Red Cross understood that it would be very difficult for her to block Germany for the third time, as even the Belgians were becoming less vehement about the matter. The FRC's isolation, according to Pau, would soon become difficult and stand against the interests of the nation. But Pau did not

larger and more representative league by the mid 1920s. These changes were driven by the league as it sought to consolidate its existence vis-à-vis the ICRC by expanding its membership base, and to become the representative body within the Red Cross movement. Today, the LRCS, known as the IFRC, has 192 representative members of national Red Cross and Red Crescent societies. Please see the files in box 362.191/366, IFRC, Geneva, that pertain to Board of Governors meetings and changes in by-laws during the interwar period.

36 Ibid. The original in French reads: 'M. Ador a été fixé sur le but poursuivi par M. Davison, Grand Maître de la Ligue des Croix-Rouges'. This conflict has also been documented by Caroline Moorehead, Dunant's Dream, 261-5.

37 In letters to his daughter, Ador was explicit about how he felt about the LRCS. Those are quoted and referenced in Irène Herrmann, 'Décrypter la concurrence humanitaire: le conflit entre Croix-Rouge(s) après 1918', 93, 95, 97.

38 Aristide Briand (Président du Conseil) to France's Ambassadors in Rome and Brussels, 20 Jan. 1921. Ador's patience with the French is remarkable; see Gustave Ador to General Pau, 30 Dec. 1920, Unions Internationales 1139, MAE.

39 General Pau to Aristide Briand, 26 Jan. 1921, Unions Internationales 1139, MAE.

40 See for example Michel Marbeau, 'Un acteur des nouvelles relations multilatérales: le Service français de la Société des Nations (1919-1940)', Matériaux pour l'histoire de notre temps, 36 (1994), 11-20.

41 Président du Conseil to French Ambassador to Switzerland, 18 Mar. 1921, Unions Internationales 1139, MAE.

42 French General Consul in Geneva to French Foreign Affairs Minister, 16 Apr. 1921, Unions Internationales 1139, MAE. The consul noted that Germany made the most of France and Belgium's absence to advance its interests and concluded 'les absents ont toujours tort' (decisions are made by those in the room). 
want the FRC to yield and appear to the public as if it had forgotten its demand for the German Red Cross to denounce what the French saw as systemic and systematic violations of the Geneva Convention during the war. The FRC had to save face if it was to accept Germany within the LRCS. To that effect, it was organised that the Pope himself would make a public appeal for peace and for peoples to forget past wrong-doings so the FRC could graciously - and publicly - forgive the German Red Cross, thus assuming the highest moral ground. ${ }^{43}$ The appeal, organised by the FRC with the support of the French government through the apostolic nuncio in France, was made by Pope Pius XI, and was read during the very first plenary session of the well-attended LRCS General Assembly held in Geneva between 28 March and 1 April $1922 .{ }^{44}$ The following day, the representative of the FRC announced with great magnanimity that the FRC would defer to his Holiness's merciful wish, and therefore would not oppose Germany's request to become a member of the LRCS in $1922 .{ }^{45}$ But the feud with the German Red Cross was not over and would continue until France and Germany altered their foreign policy in the second half of the 1920 s.

\section{The LRCS's Relocation to Paris and the French Red Cross's Alignment to the Quai d'Orsay}

In the meantime, conversations about the relocation of the LRCS's headquarters from Geneva to Paris had been held. A high Swiss franc, excessive expenditures, and a difficult relationship with the ICRC had led the LRCS to review its location. ${ }^{46}$ Brussels and Paris were considered, and the decision to transfer the league to Paris was taken by the LRCS's Board of Governors on 29 March 1922. On 15 October 1921, pre-approval had been arranged to provide several months for the league's executive to negotiate the move's terms with the French government. ${ }^{47}$ Sir Claude Hill, the General Director of the LRCS, explained to representatives of the associations that formed the Central Committee of the French Red Cross that several reasons made Paris attractive for the league. ${ }^{48}$ Paris was a large international city, easy to travel to and from, a hub for scientists (it was noted that renowned doctors would not stay long in Geneva), the hygiene section of the League of Nations was working from Paris, and a low French franc represented operational savings for the largely American Red Cross-funded LRCS. Crucially, the French first asked if being settled in a neutral city, which had been the basis for the selection of Geneva in the first instance, together with the presence of the ICRC's headquarters, had lost its appeal, implying that Paris was not a neutral city. This question was a testament to the unapologetic national-patriotic character of the French Red Cross vis-à-vis the transnational humanitarianism developed by the league. Sir Claude Hill replied that the LRCS's work was peacetime work, inspired by democratic principles and that, as opposed to the ICRC, the LRCS did not need to abide by strictly neutral principles. In his view, a democratic and a neutral fabric responded to different logics, and the LRCS's governance model was that of a federated organisation where each member had a vote on the league's actions and decisions, theoretically reducing the influence of large states or wealthy national societies upon smaller ones to avoid what could result in uneven compromises under an ICRC that stood above national societies but was not exempt from their bargaining power. Sir Claude continued, 'the League is democratic by constitution. The International Committee is autonomous, Genevois and neutral'. Hill noted that this opposition in core principles had resulted in the failure to see the fusion of both institutions. ${ }^{49}$ Neither the FRC nor the French government's documents detail at length why

\footnotetext{
43 General Pau to Raymond Poincaré, 1 Feb. 1922, Unions Internationales 1136, MAE.

44 Clipping from LRCS, Vers la santé, 3, 4 (1922), 153-4, Unions Internationales 1136, MAE.

45 Ibid., 162.

46 French General Consul in Geneva to French Foreign Affairs Minister, 26 Sep. 1921, Unions Internationales 1136, MAE. It has also been argued that Geneva proved to be a difficult environment from which to operate given the presence of the ICRC; see: André Durand, From Sarajevo to Hiroshima: History of the International Committee of the Red Cross (Geneva: Henry Dunant Institute, 1984), 143-62.

47 French General Consul in Geneva to French Foreign Affairs Minister, 12 Apr. 1922, Unions Internationales 1136, MAE.

48 'Notes on the 17 Dec. 1921 conference with Sir Claude Hill', Unions Internationales 1136, MAE.

49 Ibid.
} 
France supported this relocation. The national interest or an 'obvious advantage' are mentioned but not elaborated upon. ${ }^{50}$ The level of consensus indicates, however, that both the French Red Cross and the French government were keen to see Paris remain a hub for international organisations. Those organisations increased France's national prestige and gave the French a special position within their ranks, even though in this case the LRCS was essentially perceived by the French as an American or Anglo-American-led operation. The move from Geneva to Paris began on 1 August $1922 .{ }^{51}$ The LRCS's new offices were temporarily housed at 7 rue Quentin-Bauchart before being moved to 2 Avenue Vélasquez on 23 October 1922.

During Pau's presidency of the Central Committee from 1918 to 1932, the French Red Cross was perfectly aligned with the Quai d'Orsay (the French Foreign Office) with regard to the international matters it dealt with. By inclination, the FRC was national and patriotic, rather than humanitarian and transnational. At the time, this trait was not uncommon among national Red Cross societies that had often been born from patriotic initiatives. While they collaborated at international level, some, such as the Japanese national society, were closely aligned to their state. Files preserved at the MAE's archives testify to the level of political guidance sought by the Central Committee of the French Red Cross on a wide range of issues that pertained to the international aspects of its activities. In January 1920, Pau wrote to the Foreign Affairs Minister wishing to establish a 'continuing harmony' with the Quai d'Orsay, with 'regular exchanges' in order to uphold 'French interests in the pursuit of our humanitarian works ... in agreement with the Minister for Foreign Affairs'. ${ }^{52}$ To this end the Central Committee of the French Red Cross created a new branch within its organisation chart, the service des questions extérieures, headed by M. De la Boulinière, a former diplomat, trusted by and respected at the Quai d'Orsay. M. de la Boulinière also became the deputy to M. de Kergorlay, the French representative at the LRCS's Board of Governors. Pau stated that anytime that a decision of the Central Committee would touch upon questions of 'national interest', De la Boulinière 'will make sure of [the Minister's] assent', to ensure 'complete harmony with the French Government's views'. ${ }^{53}$ The French foreign minister readily agreed to Pau's proposal, writing: 'I hasten to let you know that I greet [your proposal] with the utmost favour'. ${ }^{54}$ Under Pau, the French Red Cross, a traditional auxiliary of the French army, became an auxiliary to the French Foreign Office, a semi-official and semi non-official channel through which to advance French diplomacy. It is not that the French Red Cross substituted a ministry (of War) for another (Foreign Affairs) to work in conjunction with the French government; in the interwar, the FRC remained closely associated to, and worked with, the Ministry of War. However, given that the peace treaties were mostly to be implemented diplomatically rather than militarily, the Ministry of Foreign Affairs grew in importance in the French postwar landscape. Expanding its association with a ministry of the utmost relevance ensured the continued relevance of the FRC itself, now that the war had ended. The Central Committee of the FRC identified that, in order to continue to serve the national-imperial interest and fulfil its patriotic character, it needed to secure a place and a role in France's postwar diplomatic effort. Therefore, all international activities in which the Central Committee could become involved were discussed with (for guidance and direction) or approved by the Ministry of Foreign Affairs before being undertaken. During the period covered by this article and for any foreign affairs issue, the Central Committee of the French Red Cross was, for all intents and purposes, a non-governmental branch of the French state. This was not a result of state coercion or legislation but, rather, a consequence of the infiltration of the Central Committee by high-profile personalities that had previously worked for the state - for the army, and the Foreign Office in particular - including but not limited to messieurs Pau, de Kergolay, and de la Boulinière, who sought to continue to serve the country's interests.

\footnotetext{
50 Draft letter from Herbette (MAE) to Président du Conseil, 15 May 1922, Unions Internationales 1136, MAE.

51 Sir Claude Hill (LRCS’ General Director) to French Foreign Affairs Minister, 29 July 1922, Unions Internationales 1136, MAE.

52 General Pau to the French Foreign Affairs Minister, 20 Jan. 1920, Unions Internationales 1132, MAE.

53 Ibid.

54 Alexandre Millerand to General Pau, 28 Jan. 1920, Unions Internationales 1132, MAE.
} 
The prevalence of national interests in a transnational movement such as the Red Cross was not unique to this organisation, nor was it to France. As Andrew Webster pointed out in the case of the League of Nations, 'the gradual development of a sense of "transnational" community among these delegates was never able to overcome the more powerful imperatives of national self-interest'. To be sure, this idea of national-patriotic humanitarianism was not a new phenomenon that emerged from the First World War, but it was a dimension of some Red Cross national societies that considerably intensified as a consequence of the conflict and the resulting changing world order. Red Cross national societies such as those of France, Belgium, Germany, and Japan, for example, were national and patriotic before the war, but the great wave of international organisations strengthened by or created as a result of the war led them to engage in a form of neo-nationalism where states advanced their foreign policies through other means than foreign offices, with the assistance of non-governmental organisations. This became all the clearer in the second half of the twentieth century when new states supported the creation of new Red Cross national societies to bolster their national - and at times nationalistic - projects. Treating humanitarianism in this period as non-governmental by definition and best analysed transnationally has, therefore, some caveats, given the central role of some nationstates such as France in controlling the foreign work of the French Red Cross. This state of affairs in no way devalues or delegitimises humanitarian work delivered by national branches of international organisations but points to the relevance of the nation-state as a suitable framework to analyse post-First World War humanitarianism. What we see in the period is national humanitarianism and transnational humanitarianism being mutually constitutive.

Undoubtedly, national independence and autonomy were as central to the FRC's activities as they were to the French government. This translated into its political distribution and acceptance of humanitarian assistance and led to the politicisation of Red Cross matters. In 1923, for example, the ICRC, and Ador in particular, tactfully liaised with the French Red Cross to deal with the German Red Cross's allegations of inhumane treatment of the local population by Franco-Belgian occupation forces in the Ruhr that started in January $1923 .{ }^{56}$ This Ruhr episode is an important moment to understand how, in practical terms, representativeness constructed as neutrality by the ICRC was useful to French sovereignty. The German Red Cross, supported by the national societies of Sweden, Norway and the Netherlands, wished to launch an international appeal to help German civilians in the Ruhr, painting a very dark picture of the coalition's occupation that both the French and the Belgian authorities found slanderous. ${ }^{57}$ Elisabeth Piller has documented Germany's strategic use, through propaganda in particular, of the distress of Germans during the occupation of the Ruhr in order to advocate for the revision of the Treaty of Versailles. ${ }^{58}$ This episode, although undoubtedly raising humanitarian concerns, was eminently political. The Joint Committee (LRCS and ICRC), presided over by Ador, therefore recommended sending a few ICRC delegates to this region of Germany to investigate the claims of the German Red Cross. The French identified the move of the German Red Cross as politically driven, coming from German authorities anxious to shift the conflict where it could do so: on humanitarian grounds. ${ }^{59}$ Nonetheless, French authorities facilitated the ICRC's work in the Ruhr not only because they professed to believe that the conduct of the French army was beyond reproach, but also because they could direct where, how and with whom the ICRC's inquiry could be led (we return to this idea of representativeness constructed as neutrality). France eventually authorised the ICRC's inquiry. If not handpicked directly, France at least had an opportunity to make recommendations as to which representative of the ICRC it would accept in

\footnotetext{
55 Andrew Webster, 'The Transnational Dream: Politicians, Diplomats and Soldiers in the League of Nations' Pursuit of International Disarmament, 1920-1938', Contemporary European History, 14, 4 (2005), 493.

56 On the motivations, goals, and outcomes of this occupation, see Stanislas Jeannesson, Poincaré, la France et la Ruhr 19221924. Histoire d'une occupation (Strasbourg: Presses Universitaires de Strasbourg, 1998).

57 French Ambassador to Belgium to Président du Conseil, 15 Jul. 1923, Unions Internationales 1133, MAE.

58 Elisabeth Piller, Selling Weimar: German Public Diplomacy and the United States, 1918-1933 (Stuttgart: Franz Steiner Verlag, 2020), 150-3.

59 French Foreign Affairs Minister to Gustave Ador, 26 Jul. 1923, Unions Internationales 1133, MAE.
} 
the occupied zone and under what conditions (no communication with the press being one of them). ${ }^{60}$ The French Red Cross and French authorities appreciated these types of arrangements with the ICRC, a form of flexibility and leverage they did not seem to enjoy with the LRCS, a body they viewed as more intrusive. This attitude was rationalised by the ICRC as an awareness and respect for sovereignty and sensibilities. In turn the French Red Cross was more likely to be supportive of its mission.

Unsurprisingly, one of the reports made by an ICRC delegate - a delegate previously approved by France - depicted the French as dealing humanely with German civilians in the Ruhr. The report showcased the French army's effort to feed large numbers of needy Germans. The report also concluded that there was no need for the ICRC's involvement in the Ruhr. The report, however, recognised the dire situation in which the German population languished. ${ }^{61}$ In March 1923 the ICRC had not supported the proposal of the German Red Cross to organise an international call for help for civilians in occupied regions, as the Ruhr was at the forefront of the Germans' minds: this might have incriminated the French and the Belgians. However, the ICRC did support a broader call in November 1923 to help Germany as a whole, given its economic situation. ${ }^{62}$ As Ador explained, he refused to enter the 'political terrain' of the occupation of the Ruhr onto which the Germans tried to lead him in order to focus on broader (and less controversial) 'humanitarian terrain', insisting on his impartiality. ${ }^{63}$

Several months after this incident, Ador wrote to the French Red Cross's Secretary, M. Thiébaut, to explain how he had prevented an international appeal that would have greatly upset France, instead opting for the recommendation of the visit of a small ICRC delegation. He also told Thiébaut of his sympathy for France, 'so scarcely supported by its former allies', while blaming Germany for its actions. Astutely, he reported that at the times of the events, the representative of the German Red Cross (M. Draudt) had received a pledge from Sir Claude Hill, the General Director of the LRCS, to support its national society 'materially and morally'. Ador concluded: 'Always the same tactic. At the very moment when, in execution of our agreements we speak of a joint action, one is acting behind our back to gain at our expense sympathies toward the League'. Ador was playing his part very well: blaming the LRCS for its change of attitude toward the German Red Cross which it now showed support to, while pledging his own support to France and its national society, and openly expressing his coolness toward Germany. ${ }^{64}$ Ador's pledged Francophilia, together with the ICRC's flexibility at this crucial moment in the history of the ICRC and the LRCS's dualism, help to explain France's regained support for the ICRC as well as its growing distaste toward the league's perceived interventionism. To French eyes, it seemed that the ICRC was more tactful with matters that the French saw as relating to their national sovereignty, and with the way it organised the representation of member states' interests, through compromise, discussion and mediation. Defending this sovereignty remained central to them and the French Red Cross. As documented by Véronique Harouel, while France supported and contributed to the elaboration of international humanitarian law as conceived by the ICRC, in the 1863-1918 period, the French Red Cross alternated frank support with firm opposition toward the committee on a wide range of issues in order to support French interests. ${ }^{65}$ This national and patriotic character became an even more distinctive feature of the French Red Cross's engagement with the ICRC and the new LRCS in the 1920s.

\footnotetext{
60 Ibid. The French Foreign Ministry negotiated the conditions unofficially through one of their staff, V. de Lacroix, a nephew of Gustave Ador, who wrote to Ador about this matter at his home address. Lacroix to Ador, 26 Jul. 1923 , Unions Internationales 1133, MAE.

61 H. Guénod (ICRC delegate) to ICRC, 28 Nov. and 3 Dec. 1923, Unions Internationales 1133, MAE.

62 Clipping from the Revue internationale de la Croix-Rouge, 59 (1923) in Unions Internationales 1133, MAE.

63 Gustave Ador to Thiébaut, 7 Dec. 1923, Unions Internationales 1133, MAE.

64 Ibid.

65 Véronique Harouel, Genève - Paris 1863-1918: le droit humanitaire en construction (Genève: Société Henry Dunant, 2003), 781-8.
} 
In 1924, Senator Ciraolo of the Italian Red Cross presented a proposal to unite international relief and mutual aid within an organisation operating under the Red Cross banner. This project formed the origins of what later became the International Relief Union (IRU). ${ }^{66}$ The idea was that in times of crises, national societies would help one another to assist local populations affected by natural or manmade disaster. The Ciraolo proposal was met with some hesitation by the FRC. In fact, France only joined the IRU in 1932, five years after it was formed. ${ }^{67}$ It is important to note that state services in France were particularly well-developed compared to other nations, including the most technologically advanced ones. France had a solid and generous public health system and assistance network, one that had traditionally been coordinated by the state, not by private associations or organisations. In countries such as the United States, where the state limited its prerogatives, the support of civil society and organisations such as the Red Cross were perhaps necessary to fill the void of missing government involvement. These shoes needed no filling in France, according to the FRC. ${ }^{68}$ Pau explained that the SSBM had traditionally been an auxiliary to the army to help the wounded, but for many decades had also been active alongside the state in situations of disasters, presenting Ciraolo's ideas and that of the LRCS as old news for the FRC. ${ }^{69}$ Pau acknowledged, however, that the density of state services in France meant that the French Red Cross was much less developed than other national societies from similar countries, and that it would not have the resources to become part of the proposed international relief organisation. Furthermore, Pau explained that the FRC preferred using its limited means to assist the French population, fighting tuberculosis and infant mortality. But the centre of his argumentation was articulated around the idea of the independence of the FRC. The FRC wished to remain independent from both the LRCS and the ICRC, and not be forced to help populations it did not want to help (the Germans in particular). The FRC wished to be able to continue to use foreign aid as a tool to advance French foreign policy. The reservations and coldness of the FRC toward the Ciraolo project came from its fears of seeing other national societies and nations interfere with what they judged as being French matters. Sovereignty and avoiding 'indiscrete curiosity' from 'certain countries' were key. ${ }^{70}$

In 1926, Ciraolo's project greatly interested the League of Nations, which was seen as a further issue by the FRC. This was because it could place the ICRC into the orbit of the League of Nations, given the ICRC's association with the IRU project primarily supported by the LRCS. Pau pleaded for the independence of the ICRC to remain untouched and declared his opposition to any move that would subordinate it, even slightly, to the League of Nations (another institution that advanced 'Anglo-Saxon' interests, according to French authorities). ${ }^{71}$ Pau stressed the importance of neutrality as being the key strength of the ICRC. He wrote that it would be an 'irreparable prejudice' to the committee if it was put in a situation of dependency toward the League of Nations through the IRU scheme. ${ }^{72}$ Pau expressed his reluctance towards the LRCS and his fear of 'Anglo-Saxon hegemony' over the Red Cross movement, and believed that its American and British leaders wanted to see the ICRC become a ceremonial body while the LRCS would control the Red Cross movement through increased mandates under the umbrella of the League of Nations. ${ }^{73}$ Pau clearly believed that French foreign policy interests ought to guide the humanitarian ideals and actions of the FRC. Acting as the

66 On the IRU, see: John F. Hutchinson, 'Disasters and the International Order: Earthquakes, Humanitarians, and the Ciraolo Project', The International History Review, 22, 1 (2000), 1-36.

67 France's joining of the IRU happened on 27 Apr. 1932; see: https://treaties.un.org/Pages/LONViewDetails.aspx? src $=$ LON\&id $=569$ \& chapter $=30 \&$ clang $=\_$fr (last visited 16 Jul. 2020).

68 On France, its state and philanthropy, see: Nicolas Duvoux, ed., 'Philanthropies et prestige d'État en France', Genèses, 109 (2017) 3-117.

69 General Pau to Raymond Poincaré (Président du Conseil and Foreign Affairs Minister), 19 Jan. 1924, Unions Internationales 1133, MAE. Frédéric Pineau, La Croix-Rouge Française 150 ans d'histoire, 46-47.

70 General Pau to Aristide Briand, 27 Mar. 1926, Unions Internationales 1133, MAE.

71 Michel Guieu, Le rameau et le glaive. Les militants français pour la Société des Nations, 53-54.

72 General Pau to Aristide Briand, 27 Mar. 1926, Unions Internationales 1133, MAE.

73 Ibid. 
representative of the FRC's main associations, he refused to countenance the FRC becoming a humanitarian branch of the League of Nations headed by the LRCS under a new international relief organisation. To him, Article 25 of the Covenant of the League of Nations 'bears the footprint of Anglo-American influence', something which remained undefined in his writings about the LRCS, often implied and pointed to, but never explicated. ${ }^{74}$ He viewed the League of Nations and the LRCS as an attack on French diplomacy, French language, and on the relationship between Catholicism and charity ${ }^{75}$ Despite the significant impact of the First World War on humanitarian practices and institutions, considering the French Red Cross in the aftermath of the conflict reveals continuities of nineteenthcentury traditions of Catholic charitable aid. While historian Keith Watenpaugh has usefully demonstrated how the war decisively introduced a technocratic, secular model of humanitarianism that he calls 'modern humanitarianism', ${ }^{76}$ the French Red Cross's insistence on a Latin and Catholic approach to its work emphasises deep and meaningful continuities with the pre-war world. ${ }^{77}$ Pau's understanding of charity during his presidency remained infused with the principles of the old world (in his own words: Latin and Christian charity), not with efficient, outcome-driven, interventionist humanitarianism. ${ }^{78}$ Pau was not alone in making this assessment. Other FRC representatives, together with French Foreign Office personnel and French senior politicians, also complained about both the LRCS's 'Anglo-Saxon' attitude and 'Anglo-Saxon' influences within it. This notion, however, was never quite defined, perhaps because what 'Anglo-Saxon' meant was obvious to them all. ${ }^{79}$ Anglo-Saxonism was associated with Protestantism, particularism, private enterprise, charity as work; in other words, the opposite of French/Latin traditions: universalism, primacy of the state, and charity as a Catholic or moral duty.

The recurrence of these debates - perceived neutrality of the ICRC versus the perceived partisanship and 'Anglo-Saxon' nature of the LRCS - is central to understanding the growing wariness of the French toward the LRCS they initially helped create. As membership expanded and the structure of the LRCS became more democratic, the French lost the small control they could have exerted over it as a founding member, because the LRCS increasingly operated as a federation. The French also knew that in times of crisis (with the First World War in the background) the very effectiveness of the ICRC was consubstantial with its neutrality and the fact that it was Geneva-based and not a representative elected body, granting it a higher authority and more neutrality. In addition, if every national society had one vote within the LRCS's decision-making bodies, it meant that France could face an 'Anglo-Saxon' bloc made up of the American, British, Indian, Canadian, South African, Australian and New Zealand national Red Cross societies, each with one vote. The FRC believed that it was much more independent and sovereign in its relationship with the ICRC than it could be with a LRCS that was potentially more coercive. For the LRCS, voting on decisions did not mean having secured a consensus with all parties, something that was the core mission of the ICRC. Additionally, the ICRC's focus on consensus and

74 Ibid.

75 The LRCS's use of English rather than French for some of its regional conferences aggrieved the French, who voiced their concerns several times on this issue in the early 1920 s.

76 'Modern Humanitarianism' according to Watenpaugh is bureaucratic, professionalised, neutral, institutional, financed and transnational. Keith Watenpaugh, Bread from Stones: The Middle East and the Making of Modern Humanitarianism (Oakland: University of California Press, 2015), 4-6.

77 This understanding of the French Red Cross's work as part of a Catholic and Latin tradition and culture was not the exclusive prerogative of the Comité central; quite the contrary. On the ground as well, some French people protested at length against 'the rationalisation of charity' by the Anglo-Americans, and their materialist approach to charity. This was most eloquently put in writing by a devout woman, Yvonne De Noël, reporting to the French Ambassador in London after completing a nursing course in 1929-30 with the League of Red Cross Societies. Yvonne de Noël to M. De Fleuriau, 21 Jun. 1930, Unions Internationales, 1136, MAE.

78 On the influence of Christianity over French charity, please refer to Adam J. Davis and Bertrand Taithe, 'From the Purse and the Heart: Exploring Charity, Humanitarianism, and Human Rights in France', French Historical Studies, 34, 3 (2011), 413-32 and Jean-Luc Marais, Histoire du don en France de 1800 à 1939. Dons et legs charitables, pieux et philanthropiques (Rennes: Presses Universitaires de Rennes, 1999).

79 Emile Chabal, 'The Rise of the Anglo-Saxon: French Perceptions of the Anglo-American World in the Long Twentieth Century', French Politics, Culture \& Society, 31, 1 (2013), 24-46. 
compromise could open the way to the informal and relative control of some humanitarian actions, or lack thereof, by great powers, as the earlier example of the Ruhr showed.

Further examples of the FRC striving for and asserting its autonomy from greater Red Cross movement interests can also be seen in colonial and overseas affairs. In that context, the kind of sovereignty sought by the FRC and France was that of an imperial nation-state whose imperial project was embedded in national ideals conveyed by the Third Republic's plus grande France. ${ }^{80}$ In 1927, Pau warned the French government against a proposed LRCS intervention in Syria (a French mandate), unless 'compulsory collaboration with the French Red Cross' was implemented because, as he explained, of the LRCS's dominant 'Anglo-American interests'. ${ }^{81}$ In other words, it was feared the LRCS would be a Trojan horse for the British in a mandate that they had previously undermined through their foreign policy. When a cyclone hit Guadeloupe - a French territory in the Caribbean - in September 1928 with catastrophic effects on the local population, Pau wrote to the French Foreign Office to ascertain if France would authorise the ICRC and LRCS's appeals, or if it was expected to rely on national (meaning French, both metropolitan and imperial) generosity and state action alone. ${ }^{82}$ Both British and American interference was feared, as it could strengthen their position in the Caribbean. Payne, from the American Red Cross (but also the Chairman of the LRCS), offered funding to assist the island's recovery and the British offered their assistance. Instead, France organised its own imperial support campaign, understood as a national effort, to showcase both French imperial unity, mutual assistance and its ability to deal with catastrophes in its own territories. Given that emergencies such as these were a state prerogative, and given the modest size of the French Red Cross, its contribution to this national fund-raising was limited. ${ }^{83}$ But these reactions were not solely driven by fears of Anglo hegemony. They very much responded to internal logics of France as an imperial nation-state eager to assert its authority on colonies and mandates in a moment of anti-colonialism. These two factors combined meant that the French state felt both too important and too vulnerable to support the democratic model of humanitarian representativeness proposed by the LRCS.

\section{Toward a Union of the LRCS and the ICRC? The French Red Cross's Position}

In the early 1920s, many meetings were held to design an organisational model for the International Red Cross whereby the LRCS and the ICRC would merge. Now that the LRCS existed, the ICRC was no longer alone in its dealing with national societies. The dualism between the two organisations, and the extent of the scope of their respective action, created some confusion for national societies that sought clarifications from each body and, possibly, their union. In 1922, the fusion of the two institutions failed, and various commissions were formed in the following years, some proposing new status inspired by ICRC principles (neutrality, independence), others inspired by LRCS principles (federation, democratic, cooperation with the League of Nations). ${ }^{84}$ Supporters of the LRCS (the American and British Red Cross in particular) advocated for a truly federated model, in which every member state could vote on decisions, following the model of the League of Nations. France and its national Red Cross society, together with other national societies, opposed this model because they envisaged that the richest societies (to which they did not belong) would dictate the agenda of the International Red Cross, turning democratic aspirations into oligarchic leadership. ${ }^{85}$ Furthermore, if

80 Gary Wilder, The French Imperial Nation-State. Negritude and Colonial Humanism between the Two World War (Chicago: University of Chicago Press, 2005).

81 General Pau to Aristide Briand, 25 Mar. 1927, Unions Internationales 1133, MAE.

82 General Pau to Aristide Briand, 19 Sep. 1928, Unions Internationales 1133, MAE.

83 Livre d'or de la reconnaissance guadeloupéenne, cyclone du 12 Sep. 1928, (Basse Terre Imprimerie officielle: Ministère des Colonies, 1931) https://issuu.com/scduag/docs/mmc16031 (last visited 21 Jul. 2020).

84 Commission d'Etude de l'Organisation de la Croix-Rouge Internationale, 'rapport aux sociétés nationales de la Croix-Rouge', 1 Feb. 1924, 1, Unions Internationales 1135, MAE.

85 A handwritten comment from an unidentified staff of the MAE on a note titled 'résolutions que soumettra le Colonel Olds le lundi 21 Janvier', Unions Internationales 1135, MAE. 
the International Red Cross adopted a representative and democratic model, its neutrality and independence would be diminished by partisanship. The argument at play here was that humanitarianism could not be put to the vote, that the International Red Cross could not operate like a standard democratic institution, and that it needed to be above representativeness and partisanship, particularly if that representativeness risked corruption by the wealthy 'Anglo-Saxon' bloc. This was also a debate that spoke to the core of how representativeness ought to be achieved within the international Red Cross world: through an aggregation of votes or via consensus building behind the scenes. If the ICRC was to be given a seat and a vote within a federated organisation it would lose the very agent of its effectiveness: independence, neutrality and its moral authority. The distinctive 'postwar-ness' of the politics of representativeness was heavily influenced by the prestige the ICRC had acquired through its POW work, and the instrumentalisation of that prestige (by the French in this instance). For the French, the implications of a federated model for the International Red Cross were significant. If a federated democratic body with decision-making powers was created it would be led by the richest societies (the United States in particular), isolating France and advancing their interests through the soft power conferred by the Red Cross banner. The FRC much preferred its non-binding relationship with the ICRC, as it gave the FRC much agency in its national and international missions. Additionally, if the ICRC had not been the most efficient of organisations, it had proven its capacity to operate during a world war, and its dealing with prisoners of war played in its favour. In the early 1920s the FRC was aware that the dualism between the LRCS and the ICRC was not optimal, but it would not side with one or the other, preferring the status quo and the continuation of both organisations' missions. The FRC supported collaboration between those institutions but refused the absorption of one by the other. ${ }^{86}$

While the French Red Cross did not appreciate what it perceived as interventionism by the LRCS, it also acknowledged that the league had secured its existence within the Red Cross world and had a legitimate programme of works. Therefore, the FRC's position was to support some form of union between the LRCS and the ICRC in a structure in which the role and principles of the ICRC would remain secure. What the FRC wanted to avoid was the disappearance of the ICRC or the diminution of its authority within and outside the Red Cross world. At the MAE's archives in a file pertaining to its relationship to the LRCS in 1926, an undated and unsigned handwritten note - most certainly from a staff member of the ministry making a recommendation to the minister or a highranking staff - states:

We must be very wary of this institution [the LRCS] that, under the umbrella of charity, carries intense propaganda in all countries in favour of Anglo-American interests and fights everything that is Latin. Shortly after its creation it opened the hostilities against the ICRC, a much older organisation that is far more measured, limiting its action to the true aims of Red Cross's national societies .... Until now, we have always supported the two [sic] societies of the French Red Cross in its [sic] efforts to prevent that the League destroys the Committee. ${ }^{87}$

While the author of this note seems to forget that France had set the fox among the chickens in contributing to the creation of the LRCS, it does reveal that the French Foreign Office was not pleased with any form of the new institution's actual or perceived interference in its reshaping of Red Cross principles. Pau, in a letter to the Foreign Minister, was even more vocal, complaining about the 'boisterous activity of the League', its 'intrusive tendencies', 'its hegemonic designs over national Red Cross societies', its 'clear Anglo-American character' and its 'rivalry toward the ICRC' ${ }^{88}$ Clearly, Pau respected the ICRC and preferred its silences and the distance it kept from the FRC, whose autonomy it respected.

\footnotetext{
86 Weiss and Villeneuve's report (ICRC delegates), 2 Apr. 1924, Unions Internationales 1135, MAE.

87 Undated and unsigned handwritten note in Unions Internationales 1133, MAE.

88 General Pau to Aristide Briand, 12 Apr. 1926, Unions Internationales 1133, MAE.
} 
In 1926, discussions about the organising principles for the relationship between the LRCS, the ICRC and Red Cross national societies were ongoing, and the future structure of the International Red Cross was being debated. ${ }^{89}$ France reaffirmed its support for a union under an International Red Cross umbrella whereby the league and the ICRC would collaborate, but it would only do so if the ideals of the ICRC prevailed. ${ }^{90}$ Payne, however, had indicated that no committee had the jurisdiction to impose a course of action on the LRCS besides its own board, even those formed during an international conference organised by the ICRC. ${ }^{11}$ For the secretary of the French Red Cross, M. Thiébaut, it was becoming very clear that the LRCS would not want to merge in an International Red Cross organisation. He asked the French Foreign Office if France, in the event that no conciliation could be found between both institutions, should simply walk away from the LRCS. Later in 1926, as plans to unite both organisations in an International Red Cross evolved in favour of the ICRC, Thiébaut, both a diplomat and the FRC's secretary (in other words, Pau's righthand), wrote to the French Foreign Office's director for administrative affairs and international organisations to discuss the LRCS's second Pan-American Washington conference to be held from 25 May to 5 June 1926. Thiébaut reported that the LRCS was at work to avoid a union with the ICRC, and in fact wished to see the latter disappear: 'it is, as you well know, the aim that the English and American leaders of the League pursue, from the confession I forced out of Sir Arthur Stanley, President of the British Red Cross'. Furthermore, Thiébaut wrote that the league was subject to 'the same influences that, at the Society of Nations, paralyse and isolate France'. ${ }^{92}$ Thiébaut had been annoyed by a resolution passed at the Pan-American conference organised by the LRCS that stipulated that all national societies of the Red Cross would henceforth be represented at the LRCS's annual Board of Governors meeting, allegedly to abide by 'democratic principles that have to be at the base of an international organisation'. ${ }^{93}$ According to Thiébaut, this meant that what had previously been a Board of Governors meeting would now be an annual international conference of the Red Cross, relegating to the background the ICRC's conference held every three to five years. The FRC felt that the LRCS was overstepping and becoming hyperactive, and hyperactive precisely through the intensity of its democratic representative procedures.

By 1927, it was clear that no union between the two organisations would be achieved. In another unsigned document in the French Foreign Office's archives, one can read that 'the League [LRCS], under its appearance of international institution is in reality an Anglo-American organisation, funded by the United States, but headed by, not to say manipulated, by Great Britain'. ${ }^{4}$ The early 1920s had been a difficult period in the relationship between France and the United Kingdom, as their imperial interests conflicted over a number of fronts, including but not limited to Germany's position in the new world order, Kemalist Turkey, the war's debt, and Eastern Mediterranean and Middle Eastern mandates. ${ }^{95}$ France's ambivalent attitude toward its former allies was reflected in the Red Cross world and translated into a relative disengagement of the French in LRCS matters. The FRC from the late 1920s onward was not a particularly active member of the LRCS, and its relocation back to Geneva in September 1939 seemed no great loss to the FRC. The FRC's broader engagement with the Red Cross world and the ICRC in the same period was one that asserted France's independence and national interests against those of Germany but also against those of Britain, which was particularly active in curtailing French activities across the globe. It is a possibility that this attitude

\footnotetext{
89 At the Berne conference, for instance, in November 1926.

90 Thiébaut to MAE, 23 Apr. 1927, Unions Internationales 1136, MAE.

91 John Barton Payne (LRCS President) to Centurione Scotto (President of the Italian Red Cross), 4 Mar. 1926, Unions Internationales 1133, MAE.

92 Thiébaut to Harismendy (MAE's Director for Administrative Affairs and International Organisations), 28 Jul. 1926, Unions Internationales 1133, MAE. For context on this point, please refer to Susan Pedersen, The Guardians: The League of Nations and the Crisis of Empire (Oxford: Oxford University Press, 2015), 142-68.

93 Bulletin, Ligue des sociétés de la Croix-Rouge, $\mathrm{n}^{\circ} 14,15$ Jul. 1926, 23.

94 Unsigned note dated 26 Apr. 1927 in Unions Internationales 1133, MAE.

95 Stanislas Jeannesson, Poincaré, la France et la Ruhr 1922-1924. Histoire d'une occupation, 91-2.
} 
contributed to the relative hollowness of the International Red Cross, as France somewhat undermined the prospect of harmony between the LRCS and the ICRC. In 1928, positions were adopted that formalised the International Red Cross, recognising the independence of the ICRC, the LRCS and national societies, and giving them an institutionalised framework (the International Red Cross) within which to operate together. This framework remained hollow as, essentially, its members agreed to disagree when their own organisation only wanted to go a certain way on a given Red Cross matter. ${ }^{96}$

Considering the 1919-28 period, it should be said that the politicisation of the Red Cross movement was not a new phenomenon. Right from the inception of the Red Cross movement, politics played a role in shaping both aid and international humanitarian law. However, the reshuffling of the world order that followed the series of peace treaties signed after the First World War saw this politicisation shifting, with borders between the political and the humanitarian increasingly thin. The French felt that the humanitarian terrain was moved around to favour those who were in the best position to move it (be that position financial, institutional or moral). In order to be able to play its part within it, the French Red Cross progressively transitioned from being a military to a diplomatic auxiliary, or, rather, added the diplomatic feather to its cap, while remaining very close to the Ministry of War through the period. It is this new postwar context that prompted the creation of a service des questions extérieures within the Central Committee of the French Red Cross. France's status as an imperial nation-state imposed specific approaches to the politics of representativeness in the Red Cross world. The democratic model developed by the LRCS could potentially thwart French imperial and foreign affairs agendas, whereas the alleged neutrality of the ICRC became more appealing to the French because it was not a level playing field, which thus authorised France to exercise greater sovereignty. A consensus-based form of representativeness such as that cultivated by the ICRC was deemed more advantageous for France and the FRC in providing them with greater agency, rather than a vote-based and democratic model such as that developed by the LRCS. In the case of postwar France, 'the humanitarian reason', to mobilise Didier Fassin's terminology, was heavily guided by a hierarchy of interests that were meant to advance, or at least safeguard, the imperial nation-state. ${ }^{97}$ Such forces remained potent even in a humanitarian world that had become much more transnationalised and globalised.

\section{Conclusion}

The years that followed the First World War saw major reconfigurations of geopolitical dynamics across the globe which also affected France. By the end of the 1920s France was disillusioned, feeling let down by its former allies and in fact challenged by them. There was a sense of bitterness that Germany contributed so little to the reconstruction of the French territory it had utterly destroyed during its withdrawal, and that it was allowed back too quickly at the table of the great concert of nations. In 1919, within the context of fast-evolving international relations, France was prone to embarking on new initiatives through which it could perhaps secure its objectives: strengthening French diplomacy and the French empire, resisting British and American encroachments, making Germany pay the war reparations, and securing a long-term military, economic and political superiority over the former foe. This postwar context is essential in understanding the fluctuation in the relationships between the FRC and both the LRCS and the ICRC. It is clear that, in the aftermath of the war, the French Red Cross laboured to find its place within the major upheaval in the Red Cross world.

It is also important to keep in mind that the FRC was a modest national society compared to that of other powerful nations at the time. While in the United States and in the United Kingdom citizens were able to organise themselves in large and unified associations in the postwar period (for veterans,

\footnotetext{
96 David P. Forsythe, 'The International Red Cross: Decentralization and its Effects', Human Rights Quarterly, 40, 1 (2018), 74; Moorehead, Dunant's Dream, 289.

97 Didier Fassin, Humanitarian Reason: A Moral History of the Present Times (Berkeley: University of California Press, 2012).
} 
to support the League of Nations, for the Red Cross, etc.), France's associative landscape was a fractured one with a myriad of small associations much less capable of driving change because of their émiettement (crumbling, dispersion). ${ }^{98}$ Despite this, the French Red Cross, with its limited financial means, managed to weigh in on the reshaping of the Red Cross world, initially supporting the LRCS's activities and then ensuring that the ICRC would endure. It became clear that within a federation (a model advocated by the LRCS), France's voice and vote would be weak and diluted. The French Red Cross preferred the undemocratic and 'neutral' ICRC model because it was more likely to respect France's national sovereignty and autonomy, whereas the vote of a majority - especially the kinds of majority rich Anglo-Saxon great powers could mobilise - would disadvantage the minority. Within the LRCS, the FRC was only one national society, facing both the strong 'Anglo-Saxon' camp and that of its former enemies, each camp having many votes while France only had one. Asymmetrical relations were favoured by the FRC as it could rely on the weight and support of the mighty French state - its empire and army - to get its way through the Red Cross world. The FRC's progressive disengagement from the LRCS is also explained by the prerogatives the LRCS wished to see given to national Red Cross societies, which were already assumed by the French state. France had a robust and well-funded system of assistance publique, dotted with a strong network across the country. The FRC did not have the means, nor the will at the time, to carry on the entire programme of the LRCS.

In summary, and with regard to the broader international Red Cross movement, we can identify three postwar phases for the FRC. The first phase, from 1919 to 1921, witnessed strong support for the LRCS, as a way to maintain a good relationship with the Americans, undermine the ICRC, and ostracise the German Red Cross. The second phase, from 1922 to 1924, saw the FRC advocating for the status quo and the maintenance of the duality between the LRCS and the ICRC, as it gave France more leeway to choose sides on matters pertaining to the national interest. The third phase, from 1925 to 1928, saw the FRC and the French government support the ICRC so that its values and existence would not disappear or be absorbed by the LRCS under the umbrella of the League of Nations. Whether France and the FRC's understanding of the LRCS as essentially an institution that advanced American and British interests across the world can be supported from the perspectives of other members of the LRCS is uncertain. What can be concluded, however, is that the FRC saw no contradiction between the international and humanitarian objectives of the Red Cross and using its institutions to further French foreign policy objectives.

In concluding this article, it is hoped that its perspective and methodology - a focus on a national society analysed through the prism of official correspondence with its state - can be re-applied to the study of other national societies in the same period. Those of Germany, Belgium, Spain, Italy, Sweden, and the Soviet Union, for example, seem to the author particularly necessary to understand how national societies and national interests shaped the postwar Red Cross world beyond the traditional historiographical primacy granted to the American Red Cross, the ICRC and, to a lesser extent, the British Red Cross. Additionally, this article has proposed a re-appraisal of the interwar period, and the 1920s in particular: a period that has so far received scant attention in a historiography of the Red Cross world that has primarily focused on its foundational period to the First World War, and on the Second World War and the second half of the twentieth century. Knowledge of the 1920s is essential in order to understand the profound transformations of the Red Cross world, expanding the scope of its missions to peacetime work, public health, and disaster relief. The 1920s offer a glimpse into a world of opportunities for Red Cross national societies: this moment that followed the 'war to end all wars' was transformative and enabled national societies to develop their peacetime works, well before they would prepare for another war in the mid and late 1930s. Given the scale of the reconfiguration of the world order in the aftermath of the First World War, with the creation of new states, the dissolution of age-old empires and the rising power of the United States and Japan, studying how national societies of the Red Cross supported or competed against one another, how they engaged

98 Michel Guieu, Le rameau et le glaive. Les militants français pour la Société des Nations, 33-51, 288. 
with both the ICRC and the LRCS and how, in doing so, they shaped postwar humanitarianism, including in its transnational and global dimensions, seems particularly relevant to focus on the national aspect of Red Cross national societies. In other words, a focus on the national scale, or even on the national-imperial scale, does not exclude transnational approaches but enriches them and emphasises the dialectic between scales of humanitarian activity.

Acknowledgements. I am grateful to the three anonymous reviewers for shepherding this article through to publication, and to the editors for their support. I hope that they will forgive me, as a non-native English speaker, for re-using some of their excellent tournures de phrases on a limited number of occasions. I am indebted to my colleagues Matthew Fitzpatrick, Melanie Oppenheimer, Guillaume Piketty and Claire Rioult for their encouraging comments on earlier drafts. Despite this collegial support, any errors that remain in the paper are mine. This research is funded by the Australian Research Council under grant number DP190101171.

Cite this article: Fathi R (2021). Sovereignty, Democracy and Neutrality: French Foreign Policy and the National-Patriotic Humanitarianism of the French Red Cross, 1919-1928. Contemporary European History 1-19. https://doi.org/10.1017/ S096077732100062X 